\title{
APPLICATION OF PERVIOUS CONCRETE FOR PAVEMENTS: A REVIEW
}

\author{
Shaik Niyazuddin Guntakal ${ }^{1, *}$ and Senthil Selvan ${ }^{2}$ \\ Department of Civil Engineering, SRM University, Chennai- 603203, (TN) India \\ "E-mail: shaikniyazuddin.g@ktr.srmuniv.ac.in
}

\begin{abstract}
Pervious concrete also called porous concrete, permeable concrete is a special type of concrete with a high porosity which allows water from precipitation and other sources to pass directly through, thereby reducing the runoff and allowing groundwater recharge. Pervious concrete is made using large aggregates with little to no fine aggregates. The concrete paste then coats the aggregates and allows water to pass through the gap between coarse aggregates. Pervious concrete is traditionally used in parking areas, areas with light traffic, residential streets, pedestrian walkways, and greenhouse. It is an important application for sustainable construction and is one of many low impact development techniques used by builders to protect water quality. Pervious concrete pavement is a unique and effective means to meet growing environmental demands. It is instrumental in recharging groundwater and in reducing stormwater runoff. This paper reviews the research developments in pervious concrete. The experimental investigations performed to know the various properties of pervious concrete like mechanical properties, hydrological properties have been reviewed. It helps to eliminate retention ponds, swales and reducing the cost by not using a huge area for this purpose. Pervious concrete can be used for many numbers of applications, but its primary usage is in pavement industry. It is very useful for rural pavements and has a wide scope for further research, which will be a promising roadway material in future to recharge ground water.
\end{abstract}

Keywords: Pervious concrete, pavement, strength, permeability, durability, environment.

(C) RASĀYAN. All rights reserved

\section{INTRODUCTION}

Presently natural resources are increasingly consumed due to rapid urbanization. Because of this, various strategies are being investigated by Engineers to protect and restore natural ecosystems in the world ${ }^{1}$. Stormwater management has become a prime factor for cities and municipalities due to increased urbanization ${ }^{2}$.

The impervious nature of conventional pavement systems has resulted in increased stormwater runoff quantity that has stemmed in a large volume of first flush containing unacceptable level of pollutants and unwarranted flash floods. ${ }^{3-6}$

The impervious pavement acts as a heat storage media release the heat back into the atmosphere during night times. Because of which, Urban Heat Islands ( UHI) has to lead to thermal discomfort which will increase the electricity bills and increase in $\mathrm{CO}_{2}$ emissions due to high usage of air conditioners. To reduce the impact of urbanization, a lot of research is going on to use eco-friendly materials ${ }^{7-9}$ and adopted detention and retention basins to reduce runoff ${ }^{10}$.

By considering all strategies, to reduce the effect of urbanization on groundwater and other environmental factors, the pervious concrete pavement is considered as the best solution in structural, hydrological, economic point of view ${ }^{11}$. The research on pervious pavement materials has been in developed countries such as USA and Japan since 1980's ${ }^{12}$.

Pervious concrete is a mixture of Portland cement, water, coarse aggregate and in some cases, chemical admixtures. The absence of fine aggregate helps in increasing the voids and water can pass through these voids and reaches to ground level. It has relatively stiff consistency, which dictates its handling and placement requirements. The main purpose of this review paper is to provide knowledge to the researcher about the pervious concrete material and its advantages. There is a lot of scope for research in this area, which helps to protect our environment and ground water resources. 


\section{RASĀYAN J. Chem.}

Vol. 10 | No. 1 |32-36 | January - March | 2017

\section{EXPERIMENTAL}

Researchers conducted different experimental investigations like aggregate investigation, the effect of aggregate properties, the effect of aggregate size and gradation, optimal mix, admixture investigation, optimum water to cement ratio, failure analysis with admixtures and without admixtures.

\section{Materials}

Aggregates of different sizes and shapes are used to investigate the properties of concrete. Cementing materials is used to provide coating around the aggregates and to increase the durability of pervious concrete. Water-reducing admixtures are used to increase the workability without increasing the water content.

\section{Aggregates}

In Pervious concrete, various sizes of coarse aggregate range from $9.5 \mathrm{~mm}$ to $19 \mathrm{~mm}^{13}$ are used without fine aggregate and the addition of admixtures. However, to increase the strength of pavement it is necessary to decrease the size of aggregate. The aggregate content ratio used by various authors is shown in the table (1) for different aggregate to cement ratio and for different water to cement ratio.

Igneous rocks are preferable as coarse aggregate for concrete due to their higher strength. The physical properties of aggregates to be used in pervious concrete should be similar to conventional concrete. Dolomite is best suitable aggregate, which provides higher compressive strength ${ }^{14}$. Typically higher strengths are achieved with angular aggregates.

Table-1: Mix proportions used by various Researchers

\begin{tabular}{|c|c|c|c|c|c|c|}
\hline Year & $\begin{array}{c}\text { Aggregate } \\
\left(\mathrm{Kg} / \mathrm{m}^{3}\right)\end{array}$ & $\begin{array}{l}\text { Cement } \\
\left(\mathrm{Kg} / \mathrm{m}^{3}\right)\end{array}$ & $\begin{array}{c}\text { Water } \\
\left(\mathrm{Kg} / \mathrm{m}^{3}\right)\end{array}$ & $\begin{array}{c}\text { Aggregate } \\
\text { To } \\
\text { Cement ratio } \\
\text { (A/C ratio) }\end{array}$ & $\begin{array}{c}\text { Water- } \\
\text { Cement } \\
\text { Ratio } \\
\text { (W/C ratio) }\end{array}$ & Author \\
\hline 1995 & $\begin{array}{l}1740 \\
1800\end{array}$ & $\begin{array}{l}348 \\
300\end{array}$ & $\begin{array}{c}135.72 \\
125.4\end{array}$ & $\begin{array}{l}5: 1 \\
6: 1\end{array}$ & $\begin{array}{l}0.390 \\
0.418\end{array}$ & Dutta and Ghaffori ${ }^{10}$ \\
\hline 2010 & $\begin{array}{l}1486.9 \\
1586.9\end{array}$ & $\begin{array}{l}330.4 \\
352.6\end{array}$ & $\begin{array}{l}115.6 \\
123.4\end{array}$ & $\begin{array}{l}4.5: 1 \\
4.5: 1\end{array}$ & $\begin{array}{l}0.35 \\
0.35\end{array}$ & $\begin{array}{c}\text { B.Huang, H. Wu, } \\
\text { X.Shu }^{19}\end{array}$ \\
\hline 2010 & $\begin{array}{l}1524 \\
1544\end{array}$ & $\begin{array}{l}305 \\
309\end{array}$ & $\begin{array}{l}101 \\
102\end{array}$ & $\begin{array}{l}5: 1 \\
5: 1\end{array}$ & $\begin{array}{l}0.33 \\
0.33\end{array}$ & O.Deo,Neithalath ${ }^{18}$ \\
\hline 2013 & $\begin{array}{l}1560 \\
1560\end{array}$ & $\begin{array}{l}367 \\
495\end{array}$ & $\begin{array}{l}110.1 \\
148.5\end{array}$ & $\begin{array}{l}4.25: 1 \\
3.15: 1\end{array}$ & $\begin{array}{l}0.30 \\
0.30\end{array}$ & E.Lim K.H.Twan ${ }^{4}$ \\
\hline 2014 & $\begin{array}{l}1600 \\
1600\end{array}$ & $\begin{array}{l}200 \\
150\end{array}$ & $\begin{array}{c}70 \\
52.85\end{array}$ & $\begin{array}{c}8: 1 \\
12: 1\end{array}$ & $\begin{array}{l}0.35 \\
0.35\end{array}$ & A.Ibrahim,E.Mahmoud ${ }^{20}$ \\
\hline
\end{tabular}

Samples of pervious concrete with different water contents formed into a ball shown in Figure-1.In Fig.1(a), too little water is added. Due to which aggregates are not bonded with each other and lack of bonding between the aggregates reduces the compressive strength.In Fig.-1(b), the optimum amount of water is added which produces the right mix and the bondage between the aggregates is the good and compressive strength of this mix is good. In Fig.-1(c), Excessive water is added, due to which it is more in a liquid state and less compressive strength. W/C ratio between 0.27 to 0.30 is an ideal ratio to produce quality mix and compressive strength of concrete will be more.

It is evident from the values of the table that, Dolomite is providing good dry strength when compare to Quartzite and Limestone. Dolomite is preferable to aggregate to produce a concrete which has more compressive strength.

\section{Cement}

Ordinary Portland cement (OPC) is used to produce pervious concrete ${ }^{15}$. The amount of cement used by various authors is shown in the Table-1. Cement or cementing material provides good durability and 
strength to the concrete. The thickness of cement coating plays a vital role in knowing the structural and hydrological performance of pervious concrete pavements. The increase in the size of aggregates reduces the amount of cement coating which firmly reduces the strength and increases the permeability. Pervious concrete usually has zero slumps when compare to conventional concrete.

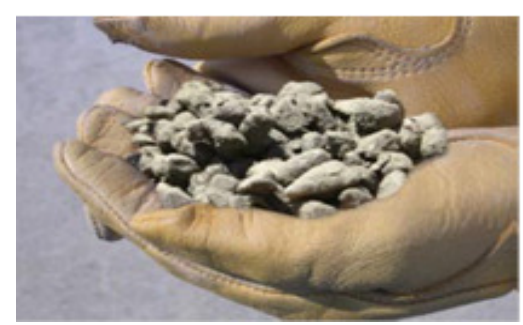

(a) Too Little water

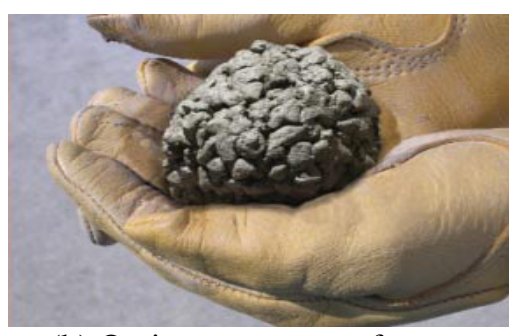

(b) Optimum amount of water

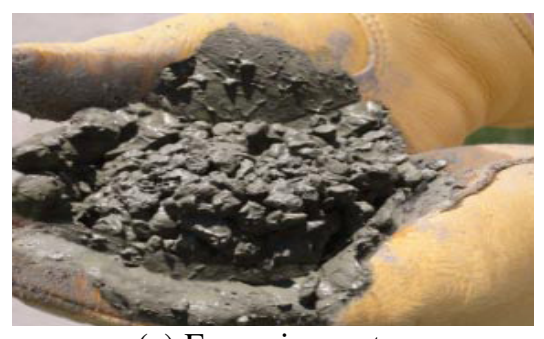

(c) Excessive water

Fig.-1: Samples of pervious concrete with different water contents formed into a ball

Table-2 : Properties of aggregate

\begin{tabular}{c|c|c|c|c}
\hline Aggregate & $\begin{array}{c}\text { Flakiness } \\
\text { Index (\%) }\end{array}$ & $\begin{array}{c}\text { Mean water } \\
\text { Absorption (\%) }\end{array}$ & $\begin{array}{c}\text { Los Angeles } \\
\text { Abrasion value (\%) }\end{array}$ & $\begin{array}{c}\text { Dry Strength } \\
(\mathrm{KN})\end{array}$ \\
\hline $\begin{array}{c}\text { Type A } \\
\text { (Quartzite) }\end{array}$ & 21 & 2.8 & 27 & 163 \\
\hline $\begin{array}{c}\text { Type B } \\
\text { (Dolomite) }\end{array}$ & 35 & 0.8 & 15 & 225 \\
\hline $\begin{array}{c}\text { Type C } \\
\text { (Limestone) }\end{array}$ & 15 & 0.3 & 38 & 74 \\
\hline
\end{tabular}

\section{Admixtures}

Mineral additives could lead to the improvement of concrete properties such as mechanical strength and durability ${ }^{1}$. Air entraining admixtures can reduce freeze-thaw damage in pervious concrete.

\section{Water}

Water to cement ratio between 0.27 to 0.30 is used successfully. The stronger paste may not increase the overall strength.

\section{Sample Preparation}

The preparation of standard concrete test specimens is based on Australian standards and guidelines. The most common principle of mix design is to provide enough cement coating to the aggregates. The coarse aggregates were washed using tap water and dried in an oven for one day to remove the silt (or) crusher dust. The mix proportions used by various authors for their investigations are shown in the Table- 1 .

Based on various principles, different mix designs and proportioning were recommended ${ }^{16-18}$. As observed, the aggregate density varies from $1400-1800 \mathrm{~kg} / \mathrm{m}^{3}$ and aggregate to cement ratio varied from $4: 1$ to $2: 1$. The water cement ratio is in the range of $0.2-0.42$.

\section{Mechanical properties}

The design thickness of the pavement and its functional characteristics are controlled by mechanical properties of pervious concrete like compressive strength, flexural strength, abrasion and free-thaw resistance test. Many researchers have worked on this ${ }^{19-21}$ properties.

\section{Strength properties}

Compressive, flexural and fatigue strength have been investigated by various researchers in the past ${ }^{22-23}$. The investigations show that strength properties are depending more on aggregate - cement ratio than water-cement ratio. The cement paste coated around the aggregate plays a vital role for more strength. As 
per past studies by various researchers, there is no big difference between 7 and 28-day flexural strength and 80 to $90 \%$ of flexural strength will be achieved in 7 days itself. It is also mentioned that the use of quarry sands will help to increase the compressive strength of concrete and addition of silica fume does not have much impact in improving the compressive strength. Few researchers ${ }^{24,25}$ developed Mathematical models to understand the mechanical behavior of pervious concrete. There is no standard test method to evaluate the compressive and flexural strength of pervious concrete

Table-3: Summary of Compressive strength characteristics of pervious concrete

\begin{tabular}{|c|c|c|c|}
\hline Year & Study parameter & Major conclusion & Author \\
\hline 1995 & $\begin{array}{l}\text { Compaction, A/C Ratio, } \\
\text { W/C Ratio }\end{array}$ & Drying Shrinkage was half of conventional concrete & $\begin{array}{l}\text { N.Ghaffori, } \\
\text { S Dutta }^{10}\end{array}$ \\
\hline 2010 & $\begin{array}{l}\text { Type of aggregate, sand, } \\
\text { silica fume }\end{array}$ & $\begin{array}{l}\text { Silica fume without admixture is not effective to } \\
\text { increase Compressive strength }\end{array}$ & C.Lian, Y.Zhuge $\mathrm{e}^{25}$ \\
\hline 2011 & Aggregate size & $\begin{array}{c}\text { Aggregate with small angularity number provides high } \\
\text { strength and less permeability }\end{array}$ & $\begin{array}{l}\text { A.K.Jain and } \\
\text { Chouhann }\end{array}$ \\
\hline 2014 & $\begin{array}{l}\text { Rubber type and Rubber } \\
\text { content }\end{array}$ & $\begin{array}{c}\text { Rubber chips have negative effect on compressive } \\
\text { strength }\end{array}$ & $\begin{array}{l}\text { M.Gesoglu, } \\
\text { E.Guneyisi }^{28}\end{array}$ \\
\hline
\end{tabular}

\section{CONCLUSION}

From the previous research carried out on pervious concrete, the following points were drawn:

- The paper has discussed various properties of pervious concrete like mechanical, hydrological, environmental, durability aspects.

- The research gaps in the previous research studies will be helpful in the overall improvement and implementation of standards for pavements.

- The main objective of this paper is to introduce the importance of pervious concrete and its benefits for rural pavements.

- Review of various papers shows that strength is inversely proportional to the permeability.

- The inclusion of silica fume did not appear to be very effective for improving the strength of porous concrete.

- The use of quarry sands will increase the compressive strength of porous concrete.

\section{ACKNOWLEDGEMENT}

The authors gratefully acknowledge to all the authors mentioned in references for their great work done on pervious concrete. The references were very useful in the preparation of this review paper.

\section{REFERENCES}

1. C.Lian, Y.Zhuge, Construction and Building Materials, 24, 2664(2010)

2. Rishi Gupta, A Pilot Study, Construction Materials, 1, 1(2014)

3. L.M. Hasalbach, S. Valavala. J. Environmental Management,81, 42( 2005)

4. E.Lim K.H. Twan, Proceedings of Eastern asia Society for Transportation Studies, Vol. 9(2013)

5. G.N. Mc Cain , M.M. Dawookar, Transportation Research Board, 1(2009)

6. Anush K. Chandrappa, Krishna Prapoorna Biligiri, Constr. Build. Mater ,111, 262(2016)

7. A.Volder, T.Watson, B. Viswanathan, Construction materials, Elsevier, 8, 249(2009)

8. Q. Wang, D.Lu.J. Schubring, Remote sense Environment, 89,46(2003)

9. M. Kolokotroni, X. Ren, Energy Buildings, 47, 302(2011)

10. N. Ghafoori, S. Dutta, J. Mater, Civil Engineering,7(3),183(1995)

11. CD.H. Nguyan, IN. Sabaibi, Construction and Building Materials, 271( 2014)

12. J.T. Harvey, T.J.Holland, Environ. Res. Lett., 8, 1(2013) 
13. ACI 522R-2010, Report on Pervious Concrete, American Concrete Institute

14. K. Cosic, L.Korat,Constr. Build. Mater., 78 , 69( 2014)

15. ASTM Standard Specification for Portland Cement, Unites States of America, 2015

16. A. Yahia, D.Kabagire, Constr. Build. Mater., 62, 38( 2014)

17. L.K.Crouch, J.Pitt, J. Mater.Civ. Eng., ASCE, 19, 561(2007)

18. O. Deo, N. Neithalath, Constr. Build. Mater., 25, 4181(2011)

19. B.Huang, H.Wu, X.Shu, Constr. Build. Mater., 24(5), 818(2010)

20. A. Ibrahim, E. Mahmoud, Constr. Build. Mater., 50 , 524( 2013)

21. J.T. Kevern, D.Biddle, J. Mater. Civ. Eng., 6, 1(2014)

22. W.D. Martin, N.B. Kaye, Constr. Build. Mater., 59, 78( 2014)

23. ASTM standard test method for flexural strength of concrete, ASTM C78,C78M-10, PA, 19428-2959 (2010)

24. C. Lian, Y. Zhuge, S. Bheecham , Adv. Mater. Res., 168, 1590(2010)

25. C. Lian, Y.Zhuge, S. Bheecham, Eng. Comput. 28 ,984(2011)

26. Y.Chen, K.Wang, Constr. Build. Mater., 42, 97(2013)

27. A.K Jain and Chouhan, Int. J. Adv. Eng. Res. Stud., 1, 120(2011)

28. M. Gesoglu, E. Guneyisi, Constr. Build. Mater., 63 , 206(2014)

[RJC-1533/2017] 